\title{
The counter-practice as an innovative educational tool to foster learning evolution of Law students
}

\section{La contrapráctica como herramienta educativa innovadora para favorecer la evolución del aprendizaje de los estudiantes de Derecho}

DOI: $10.46932 / \mathrm{sfjdv} 2 \mathrm{n} 5-067$

Received in: Oct 1st, 2021

Accepted in: Dec 30th, 2021

\author{
Núria Reguart-Segarra \\ $\mathrm{PhD}$ in Law and Lecturer in Law \& Religion \\ Universitat Jaume I \\ Spain \\ E-mail: reguart@uji.es \\ Victoria Camarero-Suárez \\ Reader in Law \& Religion \\ Universitat Jaume I \\ Spain \\ E-mail: csuarez@uji.es
}

\begin{abstract}
In view of the growing need to reinforce the students' learning process, the counter-practice is projected as an innovative educational tool capable of achieving an evolution in learning. Through this activity, which has already been implemented in the course unit of Law and Religion at the Jaume I University of Castellón (Spain), the student is granted the possibility of studying in depth a highly topical issue to prepare a legal reflection. Their previous autonomous work will be complemented and perfected with a rigorously updated legal-practical exposition by the teacher after which she will propose to the student an experimental practice with the aim of contrasting it with the legal reality. The learning evolution will take place when students are able to carry out an analysis of factual and legal basis, but enriched with the empirical contrast based on personal or third-party experiences that can lead to a major debate in relation to possible mismatches between law and social reality.
\end{abstract}

Keywords: counter-practice, learning evolution, autonomous work, legal-practical exposition, experimental practice, comparison.

\section{RESUMEN}

Ante la creciente necesidad de reforzar el proceso de aprendizaje de los alumnos, la contrapráctica se proyecta como una herramienta educativa innovadora capaz de lograr una evolución en el aprendizaje. A través de esta actividad, que ya se ha implantado en la unidad de curso de Derecho y Religión de la Universidad Jaume I de Castellón (España), se concede al alumno la posibilidad de profundizar en un tema de gran actualidad para elaborar una reflexión jurídica. Su trabajo autónomo previo será complementado y perfeccionado con una exposición jurídico-práctica rigurosamente actualizada por parte de la profesora tras la cual propondrá al alumno una práctica experimental con el fin de contrastarla con la realidad jurídica. La evolución del aprendizaje se producirá cuando el alumno sea capaz de realizar un análisis de base fáctica y jurídica, pero enriquecido con el contraste empírico basado en experiencias 
personales o de terceros que puede dar lugar a un importante debate en relación con los posibles desajustes entre el derecho y la realidad social.

Palabras clave: contrapráctica, evolución del aprendizaje, trabajo autónomo, exposición jurídicopráctica, práctica experimental, comparación.

\section{INTRODUCTION}

The learning process of undergraduate students has recently come to be conceived the core around which the whole educational system revolves (Reguart Segarra and Camarero Suárez, 2017). In consequence, it is becoming increasingly frequent for lecturers to have to plan an array of diverse activities which need to be developed throughout the academic year so that they can check that students are indeed comprehending the concepts at the right pace. However, in the case of the Bachelor's Degree in Law, this task has turned out to be particularly difficult for the teacher due to the intrinsic complexity of the subjects that have to be evaluated, in which, generally speaking, there are no wrong or right answers. Rather, their assessment strongly depends on the legal arguments adduced by the student (Reguart-Segarra, Marullo, Camarero-Suárez, Zamora-Cabot and Carceller-Stella, 2019). On too many occasions, students exclusively draw on citing legal instruments and case law — either textually or by paraphrasing-, which leaves the teacher with little to no real way of getting to discern whether students truly know what they are referring to. In light of this problem, the Area of State Ecclesiastical Law of the Jaume I University has pushed through an innovative activity which has already led to optimal results: the counter-practice ${ }^{1}$

This activity is halfway between the traditional theoretical lesson based on a master lecture, predominant in the legal domain, and the practical class in which the main character is the student. Both teaching methods need to be combined due to the fact that students frequently assume an eminently passive role in master lectures, in which they simply listen to what the teacher exposes. It is thus considered that the student is only capable of playing an active role in practical lessons, which, unfortunately, are rather scarce in the Law Degree. Unlike this worrying reality, in the counter-practice, the students' role, as well as the teachers', keep changing throughout its development in accordance with the four phases into which it is divided and that will be later on described. This innovation is projected onto the way in which students gain knowledge in two different moments (one before the master lecture and the other afterwards) and puts them into practice in front of a highly topical issue. What specifically aims at being fostered is

\footnotetext{
${ }^{1}$ This educational research draws on a previous paper published as REGUART-SEGARRA, N. and CAMARERO-SUÁREZ, V. (2020). "La evolución en el aprendizaje del alumnado a través de la contrapráctica en la asignatura de Derecho Eclesiástico del Estado" Vendrell Vidal, E. and Vega Carrero, V. (eds.). In In-Red 2020. VI Congreso Nacional de innovación educativa y docencia en red. València: Editorial Universitat Politècnica de València (pp. 61-70).
} 
learning evolution, but without leaving aside the traditional master lecture, which continues to be the quintessential organizational modality in this field.

The aforementioned activity has been put into practice in the course unit of Law and Religion that first-year Law students are compulsorily enrolled in (reference: DR1006). They are divided into two groups ( $\mathrm{A}$ and B) that tend to consist of approximately 80 students each. In addition, it has also been implemented in the course unit of the same name that is part of the first-year curriculum of the Double Bachelor's Degree in Business Administration and Law (reference: DA0106), which has been recently introduced in the Jaume I University. In this case, the approximate number of students is around 10, which enables a much closer and more thorough observation of the development of this activity. It should be mentioned that this project was first designed in the framework of the Training Programme of New Teaching Staff of the Jaume I University, in which the authors have taken part as New Lecturer (Núria Reguart-Segarra) and her Tutor (Victoria Camarero-Suárez).

\section{OVERALL OBJECTIVES}

The main objective that is pursued mainly lies in strengthening the students' progressive learning evolution. For that purpose, it is essential not only that students carry out a previous autonomous work, but also that they fully engage in the lecture in which the counter-practice is going to be put forward. Moreover, this activity aims at developing the students' ability to address, from a legal perspective, a current topic of great legal complexity related to the subject of Law and Religion, for which first-year students are not ready yet. For this reason, and in view of the serious problems that often follow the postponement of the development of this essential capacity for a lawyer to subsequent years, it has been deemed critical that students start working on it during their first year.

Hence, this teaching method aspires to boost critical thinking, reasoning and the capacity for legal argumentation of students, but it will take it all into consideration at two different points in time, as will be explained below. Above all, it positively contributes to the legal training of first-year Law students, as it has proven to be very useful in the development of a wide capacity for reflection on socio-legal problems from different points of view.

\section{DEVELOPMENT OF THE INNOVATION}

\subsection{METHODOLOGY}

As has already been pointed out, the organizational modalities upon which this activity is based are the theoretical lesson and the practical class, but, besides, a previous moment is going to be taken into account, so the individual work carried out by the student prior to the on-site development of this activity in the university classroom is crucial for obtaining the expected outcome. Thus, the teaching-learning 
methods combined are the expository method, the case study (Limpias, 2012; Pérez Fuentes, 2016; Fernández-Izquierdo et al., 2018) and problem solving.

At least one month before the date set for the development of the counter-practice, a practical task to be carried out individually by each student will be uploaded to the virtual Moodle platform (JiménezBarriosnuevo and Bolivar-Palacio, 2021). In the present case, we have opted for a legal reflection on the issue of wearing the full-face veil in European public spaces. The instructions for the completion of the task will specify that such issue should be assessed in light of the principle of religious freedom that defines the essence and identity of the Spanish State; public security as an integral element of public order; the principle of freedom of choice of women who have freely decided to wear the full-face veil; the principles of gender equality and women dignity; as well as the protection of the rights and freedoms of others as a legitimate restriction on the exercise of the right to religious freedom. From then on, students are asked to develop a critical reflection on the topic, taking as a point of departure some reference books (Camarero Suárez, 2012; Motilla, 2009; Amérigo and Pelayo, 2013).

The session in which the counter-practice is scheduled to be carried out will be organized as follows:

Table 1. Organization of the session

\begin{tabular}{cccc}
\hline Timing & Activity & Teacher's role & Student's role \\
\hline $40^{\prime}$ & Oral presentation & Active & Passive \\
$10^{\prime}$ & Counter-practice & Active & Active \\
$30^{\prime}$ & Individual & Passive & Active \\
& reflection & & \\
$40^{\prime}$ & Debate & Passive & Active \\
\hline
\end{tabular}

\subsubsection{Phase 1: oral presentation}

After the previous autonomous work that students will have developed individually without the teacher's supervision, the time comes for the completion of the counter-practice. On the day appointed for this purpose, students are expected to attend the lecture with a copy of the practical task they will have already uploaded to the Moodle platform. The session will begin with an oral presentation given by the expert in which the controversial case already examined by the students will be addressed from a viewpoint that they might find more accessible. Thus, the most current legal and jurisprudential affairs related to such an increasingly debated issue are going to be looked at. It should be born in mind that, despite the fact that the use of the full-face veil in Spain is rather minoritary, this does not prevent it from being given the importance a topic like this deserves, in which the ability of a non-denominational state to regulate one of the most striking manifestations of religious belonging is at stake.

In view of the presence of this religious symbol in some areas of Catalonia, a number of Catalan town halls decided to ban the full-face veil in certain public spaces. In particular, the agreement of the 
Lleida City Council Plenary of 8 October 2010 was brought before the Supreme Court, which gave rise to the first ruling of this first-order, decision-making forum on the full-face veil as a manifestation of the right to religious freedom ${ }^{2}$. The core of the case revolves around the possible violation of Article 16 of the Spanish Constitution, which guarantees freedom of ideology, religion and worship of individuals and communities, with no other restriction on their expression than may be necessary to maintain public order as protected by law. It should be born in mind, in the analysis of this problem, that the point of departure must be that the woman is free in her decision to wear a full-face veil and that, therefore, it falls within the scope of her freedom of choice, as she is entitled to freely decide to exercise her fundamental rights. In the present case, a fundamental right such as the right to freedom of religion had been radically limited by municipal ordinance. However, the exercise of the right to religious freedom, as a fundamental right, can only be restricted by law and, thus, municipal ordinances can only regulate subsidiary aspects of fundamental rights.

Furthermore, the Supreme Court assesses the alleged disturbance of the tranquility to which the presence of the full-face veil in our society leads, pointing out that this observation constitutes a subjective value judgment on the basis of which the establishment of a general prohibition by public authorities could never be justified. Finally, the Court considers that the principles of gender equality and women's dignity cannot, in conjunction or independently, constitute sufficient grounds to support a general ban of this religious symbol, since it should not be assumed that the woman is not free in her religious practice. In light of all of the above, the Supreme Court concludes that the general prohibition of the full-face veil suffers from a clear legal fragility, inasmuch as the limitation of the exercise of this fundamental right only applies when it is absolutely necessary for the protection of public order and the rights and fundamental freedoms of others (Article 9.2 ECHR).

Once the state of the matter in the domestic legal order has been examined, the first ruling of the European Court of Human Rights (hereinafter ECtHR) on this issue in the Case of S.A.S. v. France ${ }^{3}$ will be put forward. S.A.S. stands for the name of a Muslim French citizen born in 1990 who wears the fullface veil as a consequence of her own faith and convictions, with no third person obliging her to do so. The adoption of the French Law No. 2010-1191, of 11 October, which prohibits concealing one's face in public spaces, has a direct impact on the exercise of her right to religious freedom and she consequently decides to challenge it.

The ECtHR analysis is focused on the compatibility of the French law with Articles 8 -respect for private life- and 9 -religious freedom- of the European Convention on Human Rights (ECHR) and

\footnotetext{
${ }_{2}^{2}$ Supreme Court Judgment no. 693/2013, of 14 February, ECLI:ES:TS:2013:693.

${ }^{3}$ ECtHR Judgment on the Case of S.A.S. v. France, of 1 July 2014 (Application no. 43835/11).
} 
examines three sorts of arguments in a similar way as that of the Spanish Supreme Court. First of all, the state tried to justify its law by alleging that it was necessary to promote public safety, but the Grand Chamber found it disproportionate because of the impact that law has on women's fundamental rights. A ban on facial coverings would only be proportionate in the case of a general threat to public safety, which was not demonstrated by the French Government. As public safety might be promoted by specific controls, the general ban is not necessary in a democratic society. The Grand Chamber also rejected the reasoning of the state that the law was intended to promote respect for gender equality and respect for human dignity. Nevertheless, the state proposed and the Grand Chamber accepted that the law pursued a legitimate aim, which was the "respect for the minimum set of values of an open and democratic society", that is, the notion of "living together". Also, the Court found that, under certain conditions, the respect for the minimum requirements of life in society can be linked to the legitimate aim of the protection of the rights and freedoms of others.

The Court observes that "it indeed falls within the powers of the State to secure the conditions whereby individuals can live together in their diversity. Moreover, the Court is able to accept that a State may find it essential to give particular weight in this connection to the interaction between individuals and may consider this to be adversely affected by the fact that some conceal their faces in public places. Consequently, the Court finds that the impugned ban can be regarded as justified in its principle solely in so far as it seeks to guarantee the conditions of 'living together",4.

Regarding whether the ban was proportionate to this aim, the Grand Chamber took into account some justifications the applicant and some NGOs gave, such as the low number of women wearing the full-face veil and the negative impact on the situation of women who have decided to wear the full-face veil as a result of their convictions. The Court stated that "the question whether or not it should be permitted to wear the full-face veil in public places constitutes a choice of the society"5. Also, as in other cases, the Court held that France was granted a wide margin of appreciation. In addition, the Court observes that there is no European consensus against a ban and "consequently, having regard in particular to the breadth of the margin of appreciation afforded to the respondent State in the present case, the Court finds that the ban imposed by the Law of 11 October 2010 can be regarded as proportionate to the aim pursued, namely the preservation of the conditions of 'living together' as an element of the 'protection of the rights and freedoms of others"". Therefore, the limitation may be considered as "necessary in a democratic society" ${ }^{\prime}$. Accordingly, there was no violation of Articles 8 and 9 of the Convention.

\footnotetext{
${ }^{4}$ Ibid., at 141-142.

${ }^{5}$ Ibid., at 153.

${ }^{6}$ Ibid., at 157-158.
} 
As can be deduced, this ruling gave rise to criticism and the doctrine is not uniform about whether the full-face veil truly hinders social interaction and should be therefore banned, or if it rather constitutes an essential manifestation of the right to religious freedom that should only be limited for strict reasons of public order, when a certain danger has been proven. The ECtHR, however, appears to have ratified its decision in subsequent rulings ${ }^{7}$ regarding similar acts enacted in other European countries.

This complementary exposition aims at providing students with more information, promoting the correct understanding of complex concepts and stimulating their motivation (De Miguel Díaz, 2006, 2005a and 2005b). This is due to the fact that, even though students will have already looked at the issue before the oral presentation, its legal complexity may cause that the autonomous analysis of this problem by firstyear Law students is not entirely fruitful, since the concepts that must be dealt with are still unknown to them. Hence, the jurisprudential explanation developed by the teacher must aim at promoting the comprehension and subsequent evolution in those concepts, so the language to be used must be clear and unambiguous. To this end, the teacher must select, as methodological strategies to be used in the development of their exposition, the following:

- Giving a thorough introduction of the topic to contextualize it and awaken the students' interest, along with a brief outline of the session.

- Paying special attention to the clarity, expressiveness and rhythm of the presentation. Pauses and links are essential in this regard, as well as putting the emphasis on some concepts and giving oral summaries every short space of time.

- Carrying out a legal and jurisprudential update at the highest level, taking into consideration that this task cannot be required from students at the time of the session, as it greatly exceeds the effort expected.

- Avoiding the formulation of questions to students in this first phase, as their role is confined to assimilating what the teacher has to convey so as to undertake, by using the comparative method of contrast, the resolution of the conflict raised. The debate should be left for the end of the session, once students have listened to the teacher, have been asked to think of these two experimental situations and have reflected on them individually.

\subsubsection{Phase 2: counter-practice}

In this second phase, the counter-practice itself is finally going to be developed and, thus, both the teacher and the students will assume an eminently active role. It starts with the formulation of two personal or third-party experiences by the teacher in relation with the exposition just given. The conclusion reached by the ECtHR is that masking one's face breaks social interaction, that is, the communication among citizens. This implies that the use of the full-face veil, as a way of concealing the face, goes against living together - the minimum requirements of life in society. Based on this conclusion, the experimented and contrasted practice aims at achieving that students reflect on whether it is true that the use of the full-face veil hampers social interaction. In this counter-practice, the life experiences that the teacher raises, and in which students must engage, are the following:

\footnotetext{
${ }^{7}$ See ECtHR Judgment on the Case of Belcacemi and Oussar v. Belgium (Section 2), of 11 July 2017 (Application no. 37798/13); ECtHR Judgment on the Case of Dakir v. Belgium (Section 2), of 11 July 2017 (Application no. 4619/12).
} 
A) The teacher is at the airport waiting for the boarding gate to be shown. At the same place, there is a woman wearing a nicab. She stares at him with the deepest of her face: her eyes. She approaches him and asks him clearly whether he can tell her what the boarding gate of her flight is. The teacher realizes that it is the same gate as his, so he suggests walking together towards it. In that short space of time, they share a pleasant conversation.

B) In this second situation, it is the teacher who needs some help, as he is completely lost. A woman walks past him, but she is listening to music on her smartphone, totally absorbed in her own world and staring exclusively at her phone. With this attitude, it should be understood that this woman seems to express that she prefers to stand aside others' problems, so the teacher desists from asking her for help. She has a right to be an outsider. The law, fortunately, does not preclude her from doing so, unlike what happens in France with every woman wearing a full-face veil, with the ECtHR approval.

By exposing such experiences, students will have to reflect and position themselves on whether it is true that the full-face veil prevents per se social interaction or whether it has proven to be useful in order to put tolerance into practice and empathyse with the other. Students are thus expected to place themselves in the situation of the different in an integration model that should not be hindered, for instance, by a general prohibition, which is nothing more than a disproportionate and unnecessary blow of authority.

\subsubsection{Phase 3: individual reflection}

In this third phase, students are going to assume the leading role. After listening to an expert giving an oral presentation on the matter, and once these two personal experiences -in clear contrast between each other- have been put forward, students must reanalyze the same legal arguments that they will have already looked at before the session, but at this stage they will have a socio-legal background at a much higher level, which will enable them to reach a final decision in favour or against the problem raised. Hence, the student must decide, in light of the legal reasoning of both the Spanish Supreme Court and the ECtHR, as well as by taking account of the different acts adopted in the European context, whether the ban on the general use of the full-face veil in European public spaces is legitimate. The final conclusion reached by the student in this third phase does not necessarily have to coincide with the first one they reached, that is, the one that appears in the task uploaded to the Moodle platform prior to the start of the session. Thus, the students must be aware that both the task completed at home and the final legal reflection to which they will arrive in class, and that must be written down and handed in to the teacher before the end of the session, will be taken into consideration when marking the overall activity as part of their continual assessment. 


\subsubsection{Phase 4: debate}

In the last phase of this activity, the debate will be open to the whole class, so that they can put in common their agreement or disagreement with the verified reality. They will be able to realize if most of them have evolved in their learning process thanks to the counter-practice or if they remain stuck in a way of thinking that has not allowed them to move forward. At this stage, the teacher will assume the role of moderator of the debate, so their performance will be limited to giving the floor to those who want to take part, preventing them from not listening to each other and, above all, the teacher will be in charge of making sure students do not leave behind strict legal arguments to start wielding personal opinions, which are outside the legal-practice sphere. In addition, students must actively engage in the debate and in the reflections that it may lead to. Thus, students must put aside their fears and insecurities so that they are able to speak in front of their peers standing up for their own positioning without an excessive emotional effort.

\subsection{SKILLS ACQUIRED}

The competences students are expected to acquire revolve around the assimilation of the incidence and legal problems around the right to religious freedom and its manifestations in the public sphere. Referring to specific competences, it is worth highlighting:

- Management and use of the sources of State Ecclesiastical Law.

- Consultation of case law and relevant doctrine for the object of study.

- Greater understanding of the right to religious freedom as the first human right of the person, the most radical and intimate, the exercise of which can only be limited in exceptional situations.

- Analysis of the problem raised from a legal-sociological perspective and through a wide range of different legal arguments that can even oppose to each other.

- Legal reflection in favour or against the general prohibition of the full-face veil in the public space in light of all the above.

- Evolution in the initial legal reflection after the completion of the counter-practice.

\section{RESULTS}

In the academic year 2018/19, which represents the first time this activity was put into practice, a total number of 160 students participated in the counter-practice (taking into account both the numerous group of the Bachelor's Degree in Law and the reduced number of students of the Double Bachelor's Degree), of whom up to 135 demonstrated to have evolved positively in their learning process, which means that their final conclusion after the completion of the activity moved towards a greater understanding of the legal issues around the prohibition of the full-face veil in European public spaces. While 21 students continued in their initial thinking, it should be noted that their previous autonomous work showed a huge capacity of understanding and legal reasoning, so the continuity is also positive. Only 4 students showed a negative evolution, that is, after carrying out the counter-practice they baselessly 
reaffirmed themselves in a very limited reasoning that was far from the most current jurisprudential and doctrinal lines and that was therefore not consistent with the overall objectives of the activity. This indirectly shows that it is a crucial factor not only paying careful attention to both the oral presentation and the counter-practice itself, but also carrying out a satisfactory preparatory work.

During the following academic year, the Covid-19 pandemic arouse and the counter-practice could not be put into practice, that is why the subsequent data gathered refers to the academic year 2020/21. In this case, the total number of students enrolled in the course unit of Law and Religion was 178, of whom up to 142 showed a positive evolution, 33 continued in their initial positive thinking and only 3 showed a negative evolution.

The analysis of the data obtained has based on the following criteria:

- Positive evolution. This qualification includes all those written individual reflections that, after having been compared with the initial practice of each student, show that they have understood the concepts conveyed by the teacher in the oral presentation and that they have been able to reflect on them and extract a conclusion based on the most up-todate jurisprudence and doctrine. The intervention in the final debate will also be assessed positively, although it is true that, for reasons of time and number of students enrolled, it is not feasible that everyone can take part in it.

- Negative evolution. The students whose evolution is marked as negative are those who have adduced exactly the same arguments and legal grounds in the practical task uploaded to the Moodle platform and in the individual reflection carried out after the counter-practice, or have brought up new arguments that have nothing to do with what has been explained by the teacher, or have used those argument in opposition to the teacher's explanation without a reasoned justification. This suggests that they have not acquired the expected competences and have not been able to follow the teacher's legal-practical presentation, so their critical reasoning has not developed as expected and it is considered that they remain stuck in their learning process. This is normally the consequence of insufficient previous preparatory work and a lack of motivation. The lack of prior preparation limits or even hinders the learning evolution and, thus, a student who has not adequately prepared the practice that must be uploaded to the Moodle platform will not be able to evolve in their learning process, since the assimilation of the concepts put forward by the teacher in the session greatly depends on the previous autonomous work carried out by each of the participants. In other words, the insufficiency in the previous preparatory work explains the non-assimilation by the student of the new concepts and, as a result, their lack of evolution in the learning process.

- Continued reasoning. In this case, while students' final reflection follows the same line as the practical task uploaded to the Moodle platform, such previous task evidenced a great deal of jurisprudential and doctrinal research, a huge coherence in their legal argumentation and in the development of their critical reasoning, and a clear exposition of the problem in line with the above. For this reason, the subsequent individual reflection does nothing more than corroborate their initial well-founded thought, enriched with what was presented in class by the teacher and by the completion of the counter-practice through the proposed life experiences.

As can be seen in the tables shown below, there is a slight difference in the percentages of observation obtained during the previous academic year, as up to 33 students have continued in their initial thinking after listening to the oral presentation in 2020/21, in comparison with the 21 students whose tasks were marked as "continued reasoning" in the academic year 2018/19. This may well be due to the fact that the extensive use of face masks as a sanitary measure to prevent the spread of the virus has changed our minds regarding the concealment of the face in public spaces and, thus, many more students have reached a positive outcome before the completion of the counter-practice. 
It should also be highlighted that students were asked to assess the activity anonymously and virtually all of them agreed on the fact that it was a very positive activity for their training, since the problem raised represents a highly topical legal issue on which more than a few venture to comment without having the technical legal knowledge required.

Table 2. Results obtained in the academic year 2018/19

\begin{tabular}{c|cccc}
\cline { 2 - 4 } & Moodle task & $\begin{array}{c}\text { Positive } \\
\text { evolution }\end{array}$ & Negative evolution & Continued reasoning \\
\hline $\begin{array}{c}\text { Number of } \\
\text { students } \\
\begin{array}{c}\text { Percentage of } \\
\text { students }\end{array}\end{array}$ & 160 & 135 & 4 & 21 \\
\hline
\end{tabular}

Table 3. Results obtained in the academic year 2020/21

\begin{tabular}{c|cccc}
\cline { 2 - 4 } & Moodle task & $\begin{array}{c}\text { Positive } \\
\text { evolution }\end{array}$ & Negative evolution & Continued reasoning \\
\hline $\begin{array}{c}\text { Number of } \\
\text { students } \\
\begin{array}{c}\text { Percentage of } \\
\text { students }\end{array}\end{array}$ & 178 & 142 & 3 & 33 \\
\hline
\end{tabular}

In the following years, the possible variations of these percentages must be rigorously monitored. To this end, the results obtained in the two academic years analyzed in this paper will need to be compared with those obtained in subsequent years, which will in turn be crucial to verify the overall success rate of the course unit before and after the introduction of this activity.

\section{CONCLUSIONS}

It is a well-known fact that the main focus around which the current education system is articulated lies in the students' learning process. Therefore, it is in the hands of teachers to devise new educational tools and organizational modalities that favour learning and that are useful to develop the students' full capacity of understanding and assimilation of concepts. This task is deemed particularly necessary in the field of legal sciences, in which on too many occasions highly complex legal texts, doctrine and jurisprudence are used by students that do not have the level of assimilation needed, leading to negative results as regards their learning process.

As has become clear, the counter-practice has proven to be an innovative and effective activity in oder to achieve its main objective: learning evolution. A large majority of the students subject to statistics managed to evolve positively in their learning process after the completion of the counter-practice and showed great interest in its use in future practices, which yields a more than optimal result. It is for this reason that the Area of State Ecclesiastical Law of the Jaume I University will continue to bet on this 
educational tool in the next academic years and, by doing so, we will follow the students' positive assessment according to which this activity is highly beneficial for their training as jurists. 


\section{REFERENCES}

AMÉRIGO, F. and PELAYO, D. (2013). El uso de símbolos religiosos en el espacio público en el Estado laico español. Fundación Alternativas.

CAMARERO SUÁREZ, V. (2012). El velo integral y su respuesta jurídica en democracias avanzadas europeas. València: Tirant lo Blanch.

CORREA GOROSPE, J.M. (2005). "La integración de plataformas de e-learning en la docencia universitaria: Enseñanza, aprendizaje e investigación con Moodle en la formación inicial del profesorado" in Revista Latinoamericana de Tecnología Educativa, vol. 4(1), pp. 37-48.

DE MIGUEL DÍAZ, M. (2006). Metodologías de enseñanza y aprendizaje para el desarrollo de competencias. Madrid: Alianza Editorial.

DE MIGUEL DÍAZ, M. (2005a). Modalidades de enseñanza centradas en el desarrollo de competencias. Oviedo: Universidad de Oviedo, Ministerio de Educación y Ciencia.

DE MIGUEL DÍAZ, M. (2005b). Adaptación de los planes de estudio al proceso de convergencia europea. Oviedo: Servicio de Publicaciones de la Universidad de Oviedo.

FERNÁNDEZ-IZQUIERDO, M.A., MUÑOZ-TORRES, M.J., RIVERA-LIRIO, J.M., FERREROFERRERO, I., ESCRIG-OLMEDO E. and MARULLO, M.C. (2018). "The 'case study' as a teaching tool for the integration of Sustainable Development Goals" in Proceedings of EDULEARN18 Conference, IATED, pp. 4036-4041.

HUERTA, R. (2016). "Formación de docentes y defensa de los derechos humanos mediante actividades educativas en museari.com" Botti Navarro, V. and Fernández Prada, M.A. (eds.). In Libro de Actas INRED 2016: II Congreso Nacional de Innovación Educativa y Docencia en Red. València: Editorial Universitat Politècnica de València.

JIMÉNEZ-BARRIOSNUEVO, M.C. and BOLIVAR-PALACIO, M.F. (2021). "Hybrid learning environments: a significant contribution to the development of technological and collaborative skills in university teachers" in South Florida Journal of Development, vol. 2(4), pp. 5959-5970.

LIMPIAS, J.L. (2012). "El método del estudio de casos como estrategia metodológica para desarrollar habilidades investigativas en la formación del jurista" in Revista Boliviana de Derecho, no. 13, pp. 60101.

LÓPEZ GÜETO, A. (2018). "El método del caso aplicado a la enseñanza del Derecho Romano" in Docencia y Derecho, Revista para la docencia jurídica universitaria, no. 12, pp. 1-14.

LÓPEZ-SIDRO LÓPEZ, A. (2018). "Buenas prácticas en la docencia de la asignatura de Derecho y factor religioso: reflexiones desde la experiencia” in Revista General de Derecho Canónico y Derecho Eclesiástico del Estado, vol. 48, pp. 1-25.

MOTILlA, A. (coord.) (2009). El pañuelo islámico en Europa. Madrid: Marcial Pons. 
ORDEÑANA GEZURAGA, I. (2018). “Los 'One minute paper' como elemento de evaluación continua en la búsqueda de la mejora de la evaluación en una asignatura del Grado en Derecho" Vega Carrero, V. and Vendrell Vidal, E. (eds.). In Libro de Actas IN-RED 2018: IV Congreso Nacional de Innovación Educativa y Docencia en Red. València: Editorial Universitat Politècnica de València (pp. 416-427).

PÉREZ FUENTES, G.M. (2016). "Estudio de casos y hechos como modalidad activa de la enseñanza del Derecho" en Actualidad Jurídica Iberoamericana, no. 4 (bis), pp. 280-302.

PERIAGO MORANT, J.J. (2019). "TICS y Redes Sociales en derecho penal: Pensamiento analítico" Vega Carrero, V. and Vendrell Vidal, E. (eds.). In Libro de Actas IN-RED 2019: V Congreso Nacional de Innovación Educativa y Docencia en Red. València: Editorial Universitat Politècnica de València (pp. 488-501).

PONS-ESTEL TUGORES, C. and GONZÁLEZ SÁNCHEZ, M. (2018). "Materiales audiovisuales para el estudio de cuestiones de Derecho de Familia y Sucesiones a partir de la jurisprudencia de Estrasburgo" Vega Carrero, V. and Vendrell Vidal, E. (eds.). In Libro de Actas IN-RED 2018: IV Congreso Nacional de Innovación Educativa y Docencia en Red. València: Editorial Universitat Politècnica de València (pp. 220-229).

REGUART-SEGARRA, N. and CAMARERO-SUÁREZ, V. (2020). "La evolución en el aprendizaje del alumnado a través de la contrapráctica en la asignatura de Derecho Eclesiástico del Estado" Vendrell Vidal, E. and Vega Carrero, V. (eds.). In In-Red 2020. VI Congreso Nacional de innovación educativa y docencia en red. València: Editorial Universitat Politècnica de València (pp. 61-70).

REGUART-SEGARRA, N., MARULLO, M.C., CAMARERO-SUÁREZ, V., ZAMORA-CABOT, F.J. and CARCELLER-STELLA, J.J. (2019). "Integrating the 'Business and Human Rights' discourse into the university classroom through collaborative learning" in Proceedings of INTED2019 Conference, IATED (pp. 1142-1148).

REGUART SEGARRA, N. and CAMARERO SUÁREZ, V. (2017). "Los seminarios como modalidades organizativas para generar la interacción y el debate entre el alumnado" in IV Jornada Nacional sobre Estudios Universitarios y II Taller de Innovación Educativa. Competencias: Formación y Evaluación. Castelló de la Plana: Publicacions de la Universitat Jaume I (pp. 417-424).

SÁNCHEZ BAYÓN, A. (2013). "El Derecho eclesiástico en las universidades estadounidenses: su estudio mediante jurisprudencia y estudios de casos" in Revista Española de Derecho Canónico, vol. 70, núm. 174, pp. 229-265.

SUBERBIOLA GARBIZU, I. (2019a). "Claves para la creación entornos virtuales de aprendizaje de la asignatura Derecho Financiero I" Vega Carrero, V. and Vendrell Vidal, E. (eds.). In Libro de Actas INRED 2019: V Congreso Nacional de Innovación Educativa y Docencia en Red. València: Editorial Universitat Politècnica de València (pp. 11-25).

SUBERBIOLA GARBIZU, I. (2019b). "ODS en el Derecho Financiero y Tributario en la Universidad del País Vasco-Euskal Herriko Unibertsitatea" Vega Carrero, V. and Vendrell Vidal, E. (eds.). In Libro de Actas IN-RED 2019: V Congreso Nacional de Innovación Educativa y Docencia en Red. València: Editorial Universitat Politècnica de València (pp. 1503-1513). 